\title{
Do Public and Private Sector Employees Differ in Empowerment Perceptions? A Comparative Study
}

\author{
Gurvinder Kaur and Hitashi Lomash
}

\begin{abstract}
The paper is an attempt to contribute to the literature on whether public and private sector employees differ in their behaviours in the organizations. Perception of empowerment was taken up as the focus of comparison. Data . were collected from employees of public and private sector banks in India. Sample size was 200 from each type of organization. Canonical discriminant analysis was applied for the analysis. Findings prove that differences exist on the perceptions of empowerment in both the organizations.
\end{abstract}

Index Terms-Psychological empowerment, public vs. private sector, canonical discrimination.

\section{INTRODUCTION}

Had Marx been alive, he would have wondered how dark satanic mills have grown into bright Mephistophelean air-conditioned cubicles, without much of change in the concept of empowerment. When it comes to ownership, firmly established by now is the idea that significant organizational differences exist between both public and private sector. By implication, authors on the subject have assumed differences at the individual level, in both type of organizations [1].

In the backdrop of organizational design, both public and private sector can be viewed as the two ends of a continuum. By definition, public sector organizations are publicly funded, government owned and follow a bureaucratic mode of governance. The private organizations, on the other hand, are funded by in individual entities who have some or majority ownership. The mode of governance is for profit. The concept of empowerment is about a team who takes responsibility for (ownership of) the task for the organization. Therefore, the concept of empowerment in Public sector and private sector revol. ves around "ownership". The four approaches, namely, the economist approach, the political core approach, the normative approach and the dimensional approach-emphasize that the two organizations are different from each other. Theoretically, by implication, the employees would also behave differently [2]. The generic approach, on the contrary, presumes, that the practices in the two type of organizations are essentially the same. Hence, the degree to which the individuals differ in their behaviours is small. The present study is an attempt to further the research in the area by investigating a less visited but very important dimension

Manuscript received April 5, 2014; revised June 10, 2014. This paper is part of a doctoral thesis that has been submitted to Thapar University, India. The financial support for the conference has been provided by the University.

The authors are with the School of Behavioural Sciences and Business Studies, Thapar University, Punjab, India 147004 (e-mail: gurvinder@thapar edu, hitashi@thapar.edu). of human behavior - empowerment. Empowerment perceptions manifest themselves in organizational actions in relation to others. While empowerment can be affected by individual characteristics [3], it can, in turn be affected by job related and organizational characteristics also. Whether differences in ownership can cause differences in empowerment perceptions would be the focus of the paper. After discussing the construct of empowerment, a brief review of relevant work would be highlighted. Research design and methodology would be followed by results and discussions. Implications for organizations and suggestions for further research would be presented.

\section{EMPOWERMENT: THEORETICAL BACKGROUND}

Empowerment can be seen as a point in the continuum of industrial democracy. It has been treated as a motivational construct, a relational construct and at the practical level-a participative process [4].

Tracing the history of idea of empowerment, it has its roots in two diametrically opposite and contradictory domains, that is, Psychological domain and political economy with their own sets of assumptions, predictions and outcomes. Psychological perspective focuses on changing managerial attitude by bringing people together, whereas Political Economy perspective focuses on collective bargaining. In the present paper the focus is majorly on Psychological perspective with reference to the ownership of the firm. From the late eighties, ever since the concept gained popularity, the studies focused on the theory behind empowerment. The need was delineated to make organizations more effective by empowering employees. Attempts were made to draw attention to the benefits of such an approach. Conducive pratices were mentioned but the research was at best at its primary state [5]. The concept was developed conceptually as a task intrinsic motivation with four dimensions, namely, meaning fullness, self determination, competence and impact [6]. However, the construct validation of the model provided a uniform definition of Psychological Empowerment providing the much needed impetus for research [7].

Current research on empowerment can be divided clearly into two main perspectives: psychological and socio structural. The psychological approach views Employee Empowerment as a motivational construct manifested in four cognitions meaning, competence, self-determination and impact. Meaning implies the value of a work goal or purpose, judged in relation to an individual's own ideas. Competence or self-efficacy is an individual's belief in his or her ability to perform activities with skill. Where Competence is a mastery of behavior, Self-determination is an individual's sense of 
having choice in initiating and regulating actions. Impact is the degree to which an individual can influence strategic administration or operating outcomes at work. Hence, empowerment, as a psychological state, is an active work orientation where individual wishes and feels able to shape his/her work role and context [8].

The socio structural approach has its roots in Kanter's [9] theory of power in organizations. She identified the structures that are important to the growth of empowerment are access to information, being provided with appropriate resources and support to perform required tasks and access to programs that will allow individuals to develop and upgrade their work experience. Structural invol. ves the transfer of power from those who hold power and decision making authority to those down the hierarchy [10].

Structural perspective focuses on the managerial practices and policies that will facilitate empowerment. While any list of such practices cannot be exhaustive, a few practices have been discussed more widely in the empowerment literature. Since structural empowerment basically involves a movement from top down control system towards high invol. vement practices which entail sharing of rewards, information across the hierarchy, the most critical areas that need attention are-shared decision making, performance based rewards, open information flow, leadership development and training.

Though both the perspectives are important from the organizational point of view, psychological empowerment is the focus of study in comparing the perceptions of employees in private and public sector organizations.

\section{DEVELOPMENT OF HYPOTHESIS}

Despite extensive literature survey, studies comparing empowerment perceptions between public and private sector organizations could not be located. The existing literature on the subject focused on general values [11], risk assessment [12], personal values [13], terminal and instrumental value systems [14]. These studies focused on the individual factors some studies focused on the job related factors. Notable among these were job satisfaction [15], work motivation [11], work values [16], motivational factors [15]. A few authors researched organizational factors like commitment [11]-[19]; effectiveness of leadership [20]. The findings were inconclusive. In the light of the above, two conclusions can be drawn: a) lack of any comparative research on perceptions of empowerment and b) inconclusive evidence on whether public and private sector employees really differ in their behaviors. The present study assumes importance in light of the above.

The study thus proceeds with the hypothesis that- Public and private sector employees differ in their perceptions towards empowerment.

\section{RESEARCH METHODOLOGY}

Banking organizations were taken up from 10 states of Northern India. The sample size was 200 from public sector banks and 200 from private sector banks. Canonical
Discriminant analysis has been applied for analyzing and interpreting the results. Responses were collected by $12-$ item questionnaire that measured variables as defined under psychological empowerment. The measure has been validated at the individual as well as team level [20]. It has been shown to be invariant across gender [21], culture [22]-[28] and contexts [30]-[33].

\section{RESUltS AND ANALYSIS}

Descriptive statistics and canonical discriminant analysis results have been provided in the section. Discriminant Analysis (DA) is a statistical technique used to build a predictive / descriptive model of group discrimination based on observed predictor variables and to classify each observation into one of the groups. In DA multiple quantitative attributives are used to discriminate single classification variable. DA is different from the cluster analysis and the multivariate analysis of variance (MANOVA). It is different from the cluster analysis because prior knowledge of the classes, usually in the form of a sample from each class is required. On the other hand, DA is a reversed multivariate analysis of variance, MANOVA. In MANOVA, the independent variables are the groups and the dependent variables are the predictors, while in DA, the independent variables are the predictors and the dependent variables are the groups.

The common objectives of DA are i) to investigate differences between groups, ii) to discriminate groups effectively, iii) to identify important discriminating variables.

A discriminant function analysis was performed using four variables of psychological empowerment as predictors of membership in two groups of banks. Predictors were meaning, competence, self-determination and impact. The diagnostic groups were employees in public and private sector banks.

\begin{tabular}{clcc}
\multicolumn{4}{c}{ TABLE I: GROUP STATISTICS } \\
\hline Bank & \multicolumn{1}{c}{ Variable } & Mean & Std. Deviation \\
\hline Public & Meaning & 4.6267 & .47088 \\
Sector & Self-determination & 4.5208 & 40098 \\
banks & Competence & 4.1408 & .66480 \\
& Impact & 4.1058 & .74651 \\
Private & Meaning & 4.5025 & .54590 \\
sector & Self-determination & 4.3567 & .62205 \\
banks & Competence & 4.2250 & .66157 \\
& Impact & 4.2250 & .63838 \\
Total & Meaning & 4.5646 & .51292 \\
& Self-determination & 4.4388 & .52909 \\
& Competence & 4.1829 & .66369 \\
& Impact & 4.1654 & .69624 \\
\hline
\end{tabular}

\begin{tabular}{lccccc}
\multicolumn{5}{c}{ TABLE II: TEST OF EQUALITY OF GROUP MEANS } \\
\hline $\begin{array}{l}\text { Wilk's } \\
\text { Lambda }\end{array}$ & F & df1 & df2 & Sig. \\
\hline Meaning & .985 & 5.993 & 1 & 398 & .015 \\
Self-determinati & .976 & 9.841 & 1 & 398 & .002 \\
on & & & & & \\
Competence & .996 & 1.611 & 1 & 398 & .205 \\
Impact & .993 & 2.944 & 1 & 398 & .087 \\
\hline
\end{tabular}

The descriptive statistics in Table I reveal that public sector employees are showing higher levels of perceived empowerment than the private sector bank employee. Out of the individual components of psychological empowerment, 
perception regarding meaning was the highest for all the employees.

Table II depicts the results of the univariate ANOVA's, carried out for each independent variable. As can be observed, meaning and self-determination differ for the two groups.

\begin{tabular}{ccccc}
\multicolumn{5}{c}{ TABLE III: EIGEN VALUES } \\
\hline $\begin{array}{c}\text { Functio } \\
\mathrm{n}\end{array}$ & $\begin{array}{c}\text { Eigen } \\
\text { values }\end{array}$ & $\begin{array}{c}\% \text { of } \\
\text { variance }\end{array}$ & Cumulative\% & $\begin{array}{c}\text { Canonical } \\
\text { corr. }\end{array}$ \\
\hline $\mathrm{I}$ & .067 & 100.0 & 100.0 & .25 \\
\hline
\end{tabular}

An eigenvalue indicates the proportion of variance explained. A large eigenvalue is associated with a strong discriminant function. A high correlation indicates a function that discriminates well. The present correlation of 0.25 is not very high (Table III).

\begin{tabular}{ccccc}
\multicolumn{5}{c}{ TABLE IV: WILKS LAMBDA } \\
\hline $\begin{array}{c}\text { Test of } \\
\text { functions }\end{array}$ & $\begin{array}{c}\text { Wilks } \\
\text { lambda }\end{array}$ & Chi-square & Df & Sig. \\
\hline I & .937 & 25.845 & 4 & .000 \\
\hline
\end{tabular}

Wilks' lambda is the ratio of within group sums of squares to the total sum of squares. This is the proportion of the total variance in the discriminant scores not explained by the differences among groups. In the above function lambda of 0 . 963 has a significant value. ( $\mathrm{Sig}=0.000)$. Hence, the group means appear to differ (Table IV).

Table V depicts the standardized function coefficients. These can be used to rank the importance of each variable. Self-determination has a high coefficient value followed by meaning. This implies that the two groups differ a lot on these two variables. The other two variables carry negative values. This implies that public and private sector employees do not differ on these two variables.

\begin{tabular}{lc}
\multicolumn{1}{c}{ TABLE V: STANDARDIZED CANONICAL DISCRIMINANT FUNCTION COEFF } \\
\hline \multicolumn{1}{c}{ Variable } & Coefficients \\
\hline Meaning & .306 \\
Self-determination & .951 \\
Competence & -.683 \\
Impact & -.341 \\
\hline
\end{tabular}

The canonical structure matrix for the function is given in Table VI. This matrix reveals the correlations between each variables in the model and the discriminant function. These can be called the factor loadings of the variables on the discriminant function. Generally any variable with a correlation of 0.3 or more is considered to be important. Both self-determination and meaning have a positive correlation greater than 0.3 .

\begin{tabular}{ll}
\multicolumn{2}{c}{ TABLE VI: STRUCTURE MATRIX } \\
\hline \multicolumn{1}{c}{ Variable } \\
\hline Self-determination & .605 \\
Meaning & .470 \\
Impact & -.331 \\
Competence & -.245 \\
\hline
\end{tabular}

Table VII shows the unstandardised scores of the four independent variables of the construct. As can be seen meaning and self-determination are positive.
TABLE VII: UNSTANDARDISED COEFFICIENTS

\begin{tabular}{cc} 
TABLE VII: UNSTANDARDISED COEFFICIENTS \\
\hline Variable \\
\hline Meaning \\
Self-determination & .600 \\
Competence & 1.818 \\
Impact & -1.030 \\
(Constant) & -.491 \\
\end{tabular}

Table VIII summarises the number and percent of cases classified correctly and incorrectly on the basis of variables that discriminate between the two groups. The sample size for both the groups was 200 each. However, 57. 3\% of the total cases have been correctly classified.

\begin{tabular}{|c|c|c|c|c|c|}
\hline & & \multirow[t]{3}{*}{ Bank } & \multicolumn{2}{|c|}{$\begin{array}{l}\text { Predicted Group } \\
\text { Membership }\end{array}$} & \multirow[t]{3}{*}{ Total } \\
\hline & & & Public & Private & \\
\hline & & & Sector & Sector & \\
\hline \multirow{4}{*}{ Original } & \multirow[t]{2}{*}{ Count } & $\begin{array}{l}\text { Public } \\
\text { sector }\end{array}$ & 125 & 75 & 200 \\
\hline & & $\begin{array}{l}\text { Private } \\
\text { sector }\end{array}$ & 96 & 104 & 200 \\
\hline & \multirow[t]{2}{*}{$\%$} & $\begin{array}{l}\text { Public } \\
\text { sector }\end{array}$ & 62.5 & 37.5 & 100.0 \\
\hline & & $\begin{array}{l}\text { Private } \\
\text { sector }\end{array}$ & 48 & 52 & 100.0 \\
\hline & $\%$ of c & nal group & es cor & classifi & \\
\hline
\end{tabular}

\section{DISCUSSION}

The construct of Psychological empowerment, as stated earlier, has been defined as a manifestation of four behaviors. -Meaning involves a fit between the needs of one's work role and one's beliefs, values and behaviors. Competence refers to self-efficacy specific to one's work, a belief in one's capability to perform work activities with skill. Self-determination is a sense of choice in initiating and regulating one's actions [34]. Self-determination reflects autonomy over the initiation and continuation of work behavior and processes (e.g., making decisions about work methods, pace, and effort). Finally, impact is the degree to which one can influence strategic, administrative, or operating outcomes at work.

Together, these four cognitions reflect an active, rather than passive, orientation to one's work role. This measure of psychological empowerment assumes that empowerment is continuous rather than dichotomous - employees may perceive different degrees of empowerment rather than feeling empowered or not.

The discriminant analysis suggests that the best predictors for distinguishing between employees who are in the public sector and those who are in the private sector are meaning and self-determination. A closer look at the definition of the four cognitions reveal a very important dimension. Competence and impact are personality cognitions. Competence is closely related to a person's belief in his/her capability to carry out the work responsibilities. This is a variable that is affected more by belief in one self rather than the individual's work context. Employees feel powerless and low on self esteem when controlled by others. Similarly, impact, is related to the perception regarding control and 
influence over the department or relevant work area. Individual beliefs operate irrespective of the work context.

However, an active participation by the organization in shaping the perceptions of meaning and self- determination. Meaning invol. ves a fit between organizational values and individual values. The values of organization are, by obvious relation, are influenced by the type of ownership. As discussed in the beginning, both public and private sector organizations are driven by different motives. The political economy aspect of empowerment focuses on the fact the main purpose of public and private organizations is collective bargaining, which is based on the philosophy of capitalistic and socialistic previews. Both the ownership types would train people based on the philosophy they adhere to, therefore authors of the paper, based on the research follows that employee empowerment can only lead to productivity, if the organizations will focus on the coherence of psychological and socio structural dimensions effectively.

Self-determination is also affected by the autonomy, freedom and independence in taking work related decisions. Absence of role ambiguity and a clearer demarcation of authority is a pre requisite for perception of self-determination. These necessitate an active role of organization. Organizational policies, too, are geared to the organizational objectives. Hence, public and private sector employees differ in the above two variables as shown by the results.

\section{IMPLICATIONS AND SUGGESTIONS FOR FUTURE RESEARCH}

The study was carried out for banking organizations. However, the results can be generalized across other work contexts given the nature of the instrument for data collection. The study shows, very clearly, that empowerment may be a matter of perception but the organizational culture, values, internal processes; the external orientation can influence the degree of perception. This should draw the attention of the researchers to other important aspects of the empowerment process- one, the role of the organization in creating conditions that facilitate this perception and two, identifying factors that are more important in facilitating this perception. Intra and inter sector variations in the variables can be accounted for while preparing models for implementing empowerment programmes. This will contribute to the search for a universal model for implementing empowerment program.

\section{REFERENCES}

[1] H. C. Baarspul, "Do employees behave differently in public vs. private organizations?" A State -of- the-Art Review, MSc Dissertation, University of Twente, the Netherlands, 2009.

[2] P. G. Scott and S. Falcone, "Comparing public and private organizations: an exploratory analysis of three frameworks," American Review of Public Admnistration, vol. 28, no. 2, pp. 126-145, 1998.

[3] J. L. Perry and H. G. Rainey, "The public-private distinction in organization theory: a critique and research strategy," The Academy of Management Review, vol. 13, no. 2, pp. 182-201, 1988.

[4] G. M. Spreitzer, "Social structural characteristics of psychological empowerment?" Academy of Management Journal, vol. 39, pp. 483-504, 1995
[5] E. Glor, "Ideas for enhancing employee empowerment in the government of Canada?" Optimum, the Journal of Public Management, vol. 30, no. 3-4, pp. 14-21, 2011.

[6] J. A. Conger and R. N. Kanungo, "The empowerment process: integrating theory and practice," Academy of Management Review, vol. 13, pp. 471-482. 1988.

[7] G. M. Spreitzer, "Psychological empowerment in the workplace: dimensions, measurement, and validation," Academy of Management Journal, vol. 38, pp. 1442-1465, 1995.

[8] S. T. Menon, "Employee empowerment: an integrative psychological approach," Applied Psychology: an International Review, vol. 50, no. 1, pp. 153-180, 2001.

[9] R. M. Kanter, "When giants learn to dance," Mastering the Challenges of Strategy- Management and Careers in the 1990s, Rout ledge, London. 1989, pp. 44-56.

[10] N. Ozaralli, "Effects of transformational leader on empowerment and team efforts," Leadership and Organizational Development Journal, vol. 24, no. 5-6, pp. 335-344, 2003.

[11] S. T. Lyons, L. E. Duxbury, and C. A. Higgins, "Comparison of the values and copmmitment of private sector, public sector and parapublic sector employees," Public Administration Review, vol. 6, no. 4, pp. 605-618, 2006.

[12] P. C. Nutt, "Public private differences and the assessment of alternatives for decision making," Journal of Public Administration Research and Theory, vol. 9, no. 2, pp. 305-449, 2000.

[13] B. W. Becker and P. E. Connor, "Self selection or socialization of public and private sector managers? A cross cultiural values analysis," Journal of Business Research, vol. 58, pp. 111-113, 2005.

[14] R. W. Stackman, P. E. Connor, and B. W. Becker, "Sectoral ethos: an investigation of the personal values system of female and male managers in the public and private sectors," Journal Of Public Administration Research and Theory, vol. 16, no. 4, pp. 577-597, 2005

[15] M. Buelens and V. den Broeck, "An analysis of differences in the work motivation between public and private sector employees," Public Administration Review, vol. 7, no. 1, pp. 65-74, 2007.

[16] D. J. Houston, "Public service motivation: a multivariate test," Journal of Public Administration Research and Theory, vol. 10, no. 4, pp. 713-727, 2000.

[17] L. R. Goulet and M. L. Frank, "Organizational commitment across three rectors: public, non profit, and for profit," Public Personnel Management, vol. 10, no. 4, pp. 201-210, 2002.

[18] R. Hoojberg and J. Choi, "The impact of organizational characteristics on leadership effectiveness models: an examination of leadership in a public and a private organization," Administration and Society, vol. 33, no. 4, pp. 403-431, 2001

[19] M. L. Kraimer, S. E. Seibert, and R. C. Liden, "Psychological empowerment as a multidimensional construct: a test of construct validity," Educational and Psychological Measurement, vol. 59, pp. 127-142, 1999.

[20] B. L. Kirkman, P. E. Tesluk, and B. Rosen, "The impact of demographic heterogeneity and team leader-team member demographic fit on team empowerment and effectiveness," Group and Organization Management, vol. 29, no. 3, pp. 334-368, 2004.

[21] J. S. Boudarias, P. Gaudreau, and H. K. S. Laschinger, "Testing the structure of psychological empowerment: does gender make a difference?" Educational and Psychological Measurement, vol. 64, no. 5, no. 861-877, 2004.

[22] S. Aryee and Z. X. Chen, "Leader-member exchange in a Chinese context: antecedents: the mediating role of psychological empowerment and outcomes," Journal of Business Research, vol. 59, pp. 793-801, 2006.

[23] A. Ergeneli, G. Sag, I. Ari, and S. Metin, "Psychological empowerment and its relationship to trust in immediate managers," Journal of Business Research, vol. 60, no. 1, pp. 41-56, 2007.

[24] B. J. Avolio, W. Zhu, W. Koh, and P. Bhatia, "Pransformational leadership and organizational commitment: mediating role of psychological empowerment and moderating role of structural distance," Journal of Organizational Behavior, vol. 25, pp. 951-968, 2004.

[25] L. Holdsworth and S. Cartwright, "Empowerment, stress and satisfaction: an exploratory study of a call centre," Leadership and Organization Development Journal, vol. 24, no. 3, pp. 131-140, 2003.

[26] S. A. Carless, "Does psychological empowerment mediate the relationship between psychological climate and job satisfaction," Journal of Business and Psychology, vol. 18, no. 4, pp. 405-425, 2004.

[27] H. K. Spence, J. Finegan, J. Shamian, and P. Wilk, "Impact of structural and psychological empowerment on job strain in nursing work settings: 
expanding Kanter's model," The Journal of Nursing Administration, vol. 31 , no. 5, pp. 260-272, 2001 .

[28] M. Hechanova, R. Alampay, and E. Franco, "Psychological empowerment, job satisfaction and performance among filipino. service workers," Asian Journal of Social Psychology, vol. 9, pp. 92-78, 2006.

[29] D. L. Corsun and C. A. Enz, "Predicting psychological empowerment among service workers: the effect of support-based relationships," Human Relations, vol. 52, no. 2, pp. 205-225, 1999.

[30] R. T. Sparrowe, "Empowerment in the hospitality industry: An exploration of antecedents and outcomes," Hospitality Research Journal, vol. 17, no. 3, pp. 51-73, 1994.

[31] M. J. Moye, A. B. Henkin, and R. J. Egley, "Teacher-principal Relationships: exploring linkages between empowerment and interpersonal trust," Journal of Educational Administration, vol. 43, no. 3, pp. 260-277. 2004.

[32] E. L. Deci, J. P. Connell, and R. M. S. Ryan, "Elf-determination in a work organization," Journal of Applied Psychology, vol. 74, pp. 580-590, 1989

[33] N. E. Bell and B. M. Staw, "People as sculptors versus sculpture," in Handbook of Career Theory. M. B. Arthur, D. T. Hall, and B. S. Lawrence Eds., New York: Cambridge University Press, 1989.

[34] B. E. Ashforth, The Experience of Powerlessness in Organizations, Organizational Behavior and Human Decision Processes, 1989, vol. 43, pp. 207-242.

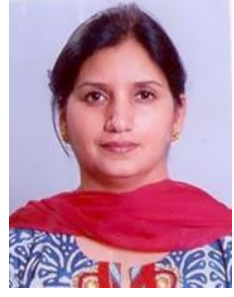

Gurvinder Kaur was born in Udhampur, in the state of Jammu and Kashmir, India, on 27 February 1968 She holds a post graduate degree in management from Guru Nanak Dev University, Amritsar India in the year 1993. She has also done her masters in economics from the same University in 1991. She completed her bachelors degree in economics from Fergusson College, University of Pune in 1989. She is a Ph.D. from Thapar University, Patiala, Punjab, India. Her doctoral research was on "employee empowerment and organizational effectiveness".

She has been working as an assistant professor in the School of Behavioral Sciences and Business Studies, Thapar University, Patiala, Punjab, India since 2002. She has worked for three years as deputy manager (planning and co-ordination) in the non banking financial sector in Punjab. She has three publications in international journals and 3 conference publications. Her current research interests include empowerment issues in workplace, organization studies, entrepreneurship, communication in organizations and human resource issues.

Ms. Kaur is a member of Academy of Management USA. 